\title{
Glucose Kinetics and Glucoregulatory Hormone Levels in Ventilated Preterm Infants on the First Day of Life
}

\author{
J. B. VAN GOUDOEVER, E. J. SUlKERS, T. E. CHAPMAN, V. P. CARNIELLI, \\ T. EFSTATOPOULOS, H. J. DEGENHART, AND P. J. J. SAUER \\ Department of Pediatrics, Division of Neonatology [J.B.V., E.J.S., V.P.C., T.E., P.J.J.S.] and Pediatric \\ Laboratory Academic Hospital Rotterdam/Sophia Childrens Hospital [H.J.D.], Erasmus University Rotterdam, \\ The Netherlands, and Mass Spectrometry Lab, Massachusetts Institute of Technology, Cambridge, \\ Massachusetts 02139 [T.E.C.]
}

\begin{abstract}
Glucose production and oxidation were measured in ventilated preterm appropriate-for-gestational-age and small-for-gestational-age infants on the first day of life. Using a new technique of $\mathrm{NaH}^{13} \mathrm{CO}_{3}$ infusion followed by a $\left[\mathrm{U}^{13} \mathrm{C}\right] \mathrm{glucose}$ infusion, we measured glucose oxidation rates without measuring the $\mathrm{CO}_{2}$ production rate. Infants were studied at $18 \pm 4 \mathrm{~h}$ (mean $\pm 1 \mathrm{SD}$ ) of life and received parenterally administered glucose only $(4.2 \pm 0.5$ $\left.\mathrm{mg} \cdot \mathrm{kg}^{-1} \cdot \mathrm{min}^{-1}\right)$. In 13 of 16 patients, the glucose production rate exceeded $1.0 \mathrm{mg} \cdot \mathrm{kg}^{-1} \cdot \mathrm{min}^{-1}$. Infants born from mothers who had been receiving steroids antenatally had higher glucose production rates $\left(2.3 \pm 1.1 \mathrm{mg} \cdot \mathrm{kg}^{-1} \cdot \mathrm{min}^{-1}\right)$ compared with infants from mothers who had not (1.1 \pm $\left.0.8 \mathrm{mg} \cdot \mathrm{kg}^{-1} \cdot \mathrm{min}^{-1}, p=0.036\right)$. The glucose oxidized $(2.9$ $\pm 1.0 \mathrm{mg} \cdot \mathrm{kg}^{-1} \cdot \mathrm{min}^{-1}$ ) was lower than the amount of glucose infused $(p=0.005)$ and was not different for appropriate-for-gestational-age and small-for-gestationalage infants. Plasma levels of glucose, insulin, glucagon, and total IGF-I were not correlated with glucose metabolism on the first day of life. Total IGF-II levels were negatively correlated with the rate of glucose appearance. We conclude that preterm infants on the first day of life receiving a glucose infusion of $4.2 \mathrm{mg} \cdot \mathrm{kg}^{-1} \cdot \mathrm{min}^{-1}$ continue to produce glucose. The glucose oxidation rate is lower than the glucose infusion rate and the contribution of glucose oxidation to the total energy expenditure is limited. (Pediatr Res 33: 583-589, 1993)
\end{abstract}

\section{Abbreviations}

Ra, rate of appearance

GPR, glucose production rate

AGA, appropriate for gestational age

SGA, small for gestational age

[U- ${ }^{13}$ C]glucose, uniformly ${ }^{13} \mathrm{C}$-labeled glucose

The fetus in utero relies on glucose as the main source of energy. Glucose is obtained from the mother by rapid flow through the placenta $(1,2)$. After birth, a shift from glucose as the major energy source to a carbohydrate-fat mixture as the energy source is observed in term infants $(3,4)$. Whether this rearrangement of metabolic fuels directly after birth also takes

Received October 15, 1992; accepted January 26, 1993

Correspondence: J. B. VanGoudoever, M.D., c/o P. J. J. Sauer, M.D., Ph.D. Sophia Childrens Hospital, Gordelweg 160, 3038 GE Rotterdam, The Netherlands. J.B.V. is supported by the Netherlands Organisation for Scientific Research (NWO). place in preterm infants is not known, but very-low-birth-weight infants often require a continuous glucose infusion to prevent hypoglycemia. However, even with a glucose infusion, these infants are prone to disturbances in glucose homeostasis during the first few days of life (5). This might be due to a limited gluconeogenesis or a glucose utilization at the same high level as in utero. Thus, to understand the disturbances in glucose level, the GPR as well as the glucose oxidation rate and the nonoxidative disposal rate have to be known.

Several studies of glucose kinetics have been performed in 1to 2-d-old neonates (6-11), but only in the study carried out by Denne and Kalhan (7) was glucose oxidation measured. The oxidation rate of fasted term infants appeared to be more than twice that in adults. No data have been published on the glucose oxidation of preterm infants directly after birth while receiving a continuous glucose infusion.

The aim of the present study was to assess the importance of glucose oxidation regarding energy metabolism in ventilated SGA and AGA preterm infants receiving a continuous infusion of glucose on the first day of life. The glucose production was measured by the stable isotope dilution technique. Serum levels of hormones involved in glucose metabolism were measured as well.

\section{SUBJECTS AND METHODS}

Patients. Ten AGA and six SGA preterm infants (11 male, five female) were included in the study. SGA infants were defined as infants with a birth weight more than 2 SD below the mean birth weight for gestation, whereas AGA infants had a birth weight between -2 and +2 SD according to the charts of Usher and McLean (12). Gestational age was determined by maternal history and Ballard score (13).

The following criteria were met by all infants studied: birth weight less than $2 \mathrm{~kg}$, artificial ventilation or continuous positive airway pressure through an endotracheal tube, venous and arterial catheter placed for clinical reasons, no congenital abnormalities, and no infusion of erythrocytes or plasma before the study.

The clinical characteristics of the infants are described in Table 1. The infants were studied between 12 and $26 \mathrm{~h}$ after birth and were kept in a thermoneutral environment throughout the study. All infants received a $10 \%$ (wt/vol) glucose infusion at $60 \mathrm{~mL}$. $\mathrm{kg}^{-1} \cdot \mathrm{d}^{-1}$, starting within $1 \mathrm{~h}$ after birth, except for one SGA infant who received a $5 \%$ (wt/vol) glucose infusion because of hyperglycemia directly after birth. The glucose infusion rate was kept constant for at least $12 \mathrm{~h}$ before the study and remained unchanged throughout the study. No enteral feedings were given before or during the study.

All infants were treated with prophylactic antibiotics (amoxi- 
Table 1. Patient characteristics*

\begin{tabular}{|c|c|c|c|c|c|c|c|c|}
\hline & GA (wk) & BW (kg) & $\mathrm{HC}(\mathrm{cm})$ & $\begin{array}{l}\text { Study age } \\
\text { (h) }\end{array}$ & $\begin{array}{c}\text { Antenatal } \\
\text { steroids }\end{array}$ & $\begin{array}{c}\text { Antenatal } \beta \text {-sympathi- } \\
\text { comimetics }\end{array}$ & $\begin{array}{l}\text { Apgar score } \\
\text { at } 5 \mathrm{~min}\end{array}$ & $\begin{array}{l}\text { Ventilatory } \\
\text { index }\end{array}$ \\
\hline \multicolumn{9}{|l|}{ AGA } \\
\hline 1 & 31 & 1.22 & 29.0 & 22 & - & - & 8 & 208 \\
\hline 2 & 31.6 & 1.84 & 31.0 & 15.5 & - & + & 6 & 21 \\
\hline 3 & 31.1 & 1.36 & 27.5 & 26 & + & + & 9 & 0 \\
\hline 4 & 30.4 & 1.19 & 28.0 & 13 & + & - & 10 & 581 \\
\hline 5 & 26.1 & 0.85 & 23.5 & 16 & + & + & 6 & 91 \\
\hline 6 & 28 & 1.28 & 26.5 & 14 & + & + & 8 & 82 \\
\hline 7 & 28.9 & 1.07 & 27.0 & 13 & - & - & 7 & 4 \\
\hline 8 & 28 & 0.94 & 24.5 & 13 & - & - & 8 & 4 \\
\hline 9 & 26 & 0.91 & 25.5 & 24 & - & + & ? & 363 \\
\hline 10 & 31.7 & 1.6 & 28.0 & 20 & - & + & 7 & 95 \\
\hline Mean AGA & $29.3 \pm 2.2$ & $1.22 \pm 0.31$ & $27.1 \pm 2.2$ & $18 \pm 5$ & $4 / 10$ & $6 / 10$ & $7.6 \pm 1.3$ & $87(4-208)$ \\
\hline \multicolumn{9}{|l|}{ SGA } \\
\hline 11 & 29 & 0.87 & 25.0 & 25 & - & - & 6 & 8 \\
\hline 12 & 29 & 0.82 & 25.0 & 18 & - & - & $?$ & 0 \\
\hline 13 & 35 & 1.08 & 30.0 & 17 & - & - & 5 & 0 \\
\hline 14 & 28 & 0.77 & 22.0 & 16 & + & + & $?$ & 47 \\
\hline 15 & 29.1 & 0.95 & 28.0 & 22 & - & + & 9 & 116 \\
\hline 16 & 30.1 & 0.84 & 25.2 & 18 & - & + & 8 & 6 \\
\hline Mean SGA & $30.0 \pm 2.5$ & $0.89 \pm 0.11$ & $25.9 \pm 2.8$ & $19 \pm 3$ & $1 / 6$ & $3 / 6$ & $7.0 \pm 1.8$ & $7(0-47)$ \\
\hline
\end{tabular}

* GA, gestational age; BW, birth weight; HC, head circumference. Group averages are presented as mean $\pm 1 \mathrm{SD}$.

cillin and cefotaxime), although no positive blood cultures were found in any of the infants. $\beta$-Sympathomimetic drugs had been given to nine mothers to inhibit uterine contractions. Several studies have shown an effect of these drugs on glucose metabolism (14-16). Corticosteroids (betamethasone) had been given to five mothers to accelerate fetal lung maturation (Table 1).

The use of stable isotopes for human investigations had been approved by the ethical committee of the Erasmus University Rotterdam. Informed consent for the study was obtained from at least one of the parents.

Methods. All infants had an endotracheal tube placed and were scored according to an adapted ventilatory scoring system (17). This ventilatory scoring system uses the concentration of oxygen in the inspiratory air $\left(\mathrm{FiO}_{2}\right)$, the mean airway pressure (MAP), and ventilatory frequency (VF) according to the following formula:

$$
\mathrm{VS}=\mathrm{VF} \times \mathrm{MAP} \times \mathrm{FiO}_{2}
$$

where VS is the ventilatory score.

Isotope infusion. ${ }^{13} \mathrm{C}$-labeled sodium bicarbonate $\left(\mathrm{NaH}^{13} \mathrm{CO}_{3}\right)$ (99\% enriched, Isotech, Miamisburg, $\mathrm{OH}$ ) and uniformly labeled glucose $\left({ }^{13} \mathrm{C}_{6} \mathrm{H}_{12} \mathrm{O}_{6}\right)(98.7 \%$ enriched, Isotech) were diluted in $0.9 \% \mathrm{NaCl}$ by the hospital pharmacy and filtered through a $0.22-$ $\mu \mathrm{m}$ Millipore filter into sterile vials.

A priming dose of $6.9 \mu \mathrm{mol} \mathrm{NaH}{ }^{13} \mathrm{CO}_{3} / \mathrm{kg}$ was followed by a continuous infusion of $4.7 \mu \mathrm{mol} \cdot \mathrm{kg}^{-1} \cdot \mathrm{h}^{-1}$ (18). This infusion lasted for $2 \mathrm{~h}$. After this period, an additional priming dose (10.4 $\mu \mathrm{mol} / \mathrm{kg}$ ) was given to prime the bicarbonate pool before the labeled glucose was infused. The $\mathrm{NaH}^{13} \mathrm{CO}_{3}$ enrichment of the solution was confirmed by conversion to ${ }^{13} \mathrm{CO}_{2}$ on an isotope ratio mass spectrometer (SIRA 10, VG Isotech Ltd., Middlewich, Cheshire, UK). After the labeled bicarbonate infusion was stopped, a primed continuous infusion of $\left[\mathrm{U}-{ }^{13} \mathrm{C}\right] \mathrm{glucose}$ was started. A priming dose of $8.7 \mu \mathrm{mol} / \mathrm{kg}$ was followed by a continuous dose of $4.8 \mu \mathrm{mol} \cdot \mathrm{kg}^{-1} \cdot \mathrm{h}^{-1}$. The infusion of the labeled glucose lasted for $5 \mathrm{~h}$. Tracers were given using a Harvard infusion pump (M22, Harvard Apparatus Co. Inc., S. Natick, $\mathrm{MA}$ ) and administered via the same infusion route as the unlabeled glucose.

Arterial blood samples were drawn before the infusion of the stable isotopes, at $30 \mathrm{~min}$ before the end, and at the end of the $\left[\mathrm{U}-{ }^{13} \mathrm{C}\right]$ glucose infusion.

Measurement of isotope dilution in plasma. Methanol $(500$ $\mu \mathrm{L}$ ) was added to $100 \mu \mathrm{L}$ of plasma to precipitate plasma proteins.
The supernatant was evaporated under nitrogen to dryness. One hundred fifty $\mu \mathrm{L} 1.2 \%$ (vol/vol) butyl boronic acid dissolved in pyridine was added to the dried glucose containing residue and heated at $95^{\circ} \mathrm{C}$ for $30 \mathrm{~min}$. The tubes were allowed to cool. Acetylation was carried out by adding $50 \mu \mathrm{L}$ acetic anhydride and leaving the tubes at room temperature for $30 \mathrm{~min}$. The derivative was washed by adding $1 \mathrm{~mL}$ of hexane and $1 \mathrm{~mL}$ of $0.1 \mathrm{~N}$ hydrochloric acid. The hexane layer was transferred to a clean test tube, evaporated to dryness, and reconstituted with $100 \mu \mathrm{L}$ of hexane.

Gas chromatography/mass spectrometry was carried out on a Hewlett-Packard (Palo Alto, CA) HP 5988A mass spectrometer coupled to an HP 5890 Series II gas chromatograph. Chromatography was carried out on a Durabond (Folsom, CA) DB 1301 fused silica capillary column. The column had a length of $30 \mathrm{~m}$, an internal diameter of $0.25 \mathrm{~mm}$, and a film thickness of 0.25 $\mu \mathrm{m}$. Selective ion monitoring was carried out at $\mathrm{m} / \mathrm{z} 297.2$ and $\mathrm{m} / \mathrm{z} 303.2$ for $(\mathrm{m})$ and $(\mathrm{m}+6)$ enrichment, respectively. The plasma glucose enrichments were determined using a calibration graph constructed from standard mixtures ranging from 0 to $0.35 \%\left[\mathrm{U}-{ }^{13} \mathrm{C}\right]$ glucose. The coefficient of variation for plasma glucose measurements in triplicate ranged from 0.8 to $4.8 \%$. The plateau glucose enrichments were calculated as percent enrichments above the baseline enrichments.

Glucose oxidation measurement. Expiratory $\mathrm{CO}_{2}$ was collected at the outlet of the ventilator. Air leaving the ventilator was led through an all-glass spiral filled with freshly prepared $\mathrm{NaOH}(1.0$ N).

Six baseline expiratory air samples were taken to determine the natural abundance of ${ }^{13} \mathrm{CO}_{2}$. One $\mathrm{h}$ after the primed $\mathrm{Na}$ $\mathrm{H}^{13} \mathrm{CO}_{3}$ infusion started, 5-min $\mathrm{CO}_{2}$ collections were performed at 10 -min intervals for $1 \mathrm{~h}$. After the [U- $\left.{ }^{13} \mathrm{C}\right]$ glucose was started, $\mathrm{CO}_{2}$ collections were made at hourly intervals for the first $3 \mathrm{~h}$, at 30-min intervals for the fourth hour, and at 10- to 15 -min intervals for the final hour. Breath samples were analyzed for enrichment of ${ }^{13} \mathrm{CO}_{2}$, as described earlier (19).

Plasma analyses. Arterial blood samples were put directly on melting ice and centrifuged at $4^{\circ} \mathrm{C}$. Plasma was divided into aliquots and stored at $-80^{\circ} \mathrm{C}$. The whole procedure did not exceed $15 \mathrm{~min}$.

Insulin and glucagon were measured (Laboratory of Endocrinology, IJsselland Ziekenhuis, Capelle a/d IJssel, The Netherlands) by an RIA in $350 \mu \mathrm{L}$ of plasma obtained at the end of the study. Blood was collected in heparinized tubes. Sensitivity of 
the assay was better than $15 \mathrm{pmol} / \mathrm{L}$ for insulin and $2.9 \mathrm{pmol} / \mathrm{L}$ for glucagon. Plasma IGF-I and IGF-II were measured in 100 $\mu \mathrm{L}$ of plasma after acidification with $0.5 \mathrm{~mol} / \mathrm{L} \mathrm{HCL}$ and 5 $\mathrm{mmol} / \mathrm{L} \mathrm{CaCl}_{2}$ and extracted using $\mathrm{C} 18$ Sep-Pak cartridges (Waters, Millipore, Milford, MA). This method effectively removes interfering binding proteins from serum. IGF levels were measured with an antiserum (IGF-I) and an MAb (IGF-II) RIA (Laboratory of Endocrinology, Wilhelmina Children's Hospital, Utrecht, The Netherlands) (20).

Glucose concentration was analyzed in a Cobas Mira (Roche, Basel, Switzerland), according to the glucose-oxidase N-(4-antipyril)-p-benzochinonimin method from Merck (Darmstadt, Germany). Blood was also obtained to measure FFA. In $100 \mu \mathrm{L}$ of serum, an enzymatic colorimetric test was performed (NEFAC, Wako Chemicals GmbH, Neuss 1, Germany).

Calculations. Turnover of glucose was calculated by dividing the tracer infusion by the mean of the two plasma measurements of the plateau of the $\left[\mathrm{U}-{ }^{13} \mathrm{C}\right] \mathrm{glucose}$ enrichment (Appendix, equation 1). The GPR was calculated by subtracting the rate of glucose infusion from the rate of glucose appearance (Appendix, equation 2)

Glucose oxidation (Appendix, equations 3-5) was determined assuming that the $\mathrm{CO}_{2}$ production during the $\mathrm{NaH}^{13} \mathrm{CO}_{3}$ infusion was equal to the $\mathrm{CO}_{2}$ production during the $\left[\mathrm{U}^{13} \mathrm{C}\right]$ glucose infusion. By determining the increase in ${ }^{13} \mathrm{CO}_{2}$ enrichment of each individual patient during both the $\mathrm{NaH}^{13} \mathrm{CO}_{3}$ infusion and the $\left[\mathrm{U}-{ }^{13} \mathrm{C}\right]$ glucose infusion, variance can be diminished and there is no need for measuring the rate of $\mathrm{CO}_{2}$ excretion (21).

Results are presented as mean $\pm 1 \mathrm{SD}$ or in cases of apparent skewness as median with the interquartile ranges between brackets. The Mann-Whitney $U$ test and the Wilcoxon signed-rank test were used for comparison between independent and paired data, respectively.

\section{RESULTS}

Figure 1 shows the plasma glucose values in each patient during the study. Mean glucose values did not alter during the study $(5.5 \pm 2.1 \mathrm{mmol} / \mathrm{L}$ at time $=0,5.5 \pm 2.8 \mathrm{mmol} / \mathrm{L}$ at time $=6.30 \mathrm{~h}$, and $5.6 \pm 2.3 \mathrm{mmol} / \mathrm{L}$ at time $=7 \mathrm{~h}$ ). The metabolic status did not alter during the study. The difference in $\mathrm{pH}$ between the start and the end of the study was $0.02 \pm 0.03$ (range $-0.03-0.08$ ) and the difference in $\mathrm{PCO}_{2}$ was $-0.3 \pm 0.5 \mathrm{kPa}$ (range $-1.3-0.6 \mathrm{kPa}$ ).

Figure 2 shows the mean increase in ${ }^{13} \mathrm{CO}_{2}$ enrichment in expiratory air. An oxidation study was not performed in two SGA infants. In the other 14 infants, two plateaus in ${ }^{13} \mathrm{CO}_{2}$ excretion were obtained, one during the $\mathrm{NaH}^{13} \mathrm{CO}_{3}$ infusion and one during the $\left[\mathrm{U}-{ }^{13} \mathrm{C}\right] \mathrm{glucose}$ infusion, allowing steady state

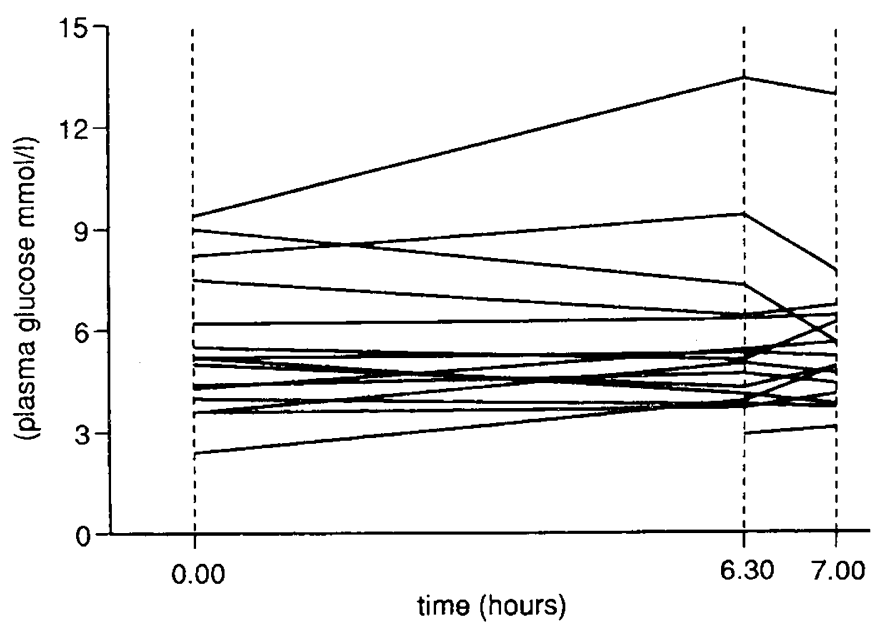

Fig. 1. Plasma glucose levels of the individual patients during the study. calculations. Plateau enrichment was determined visually and incidentally confirmed by exponential curve fitting.

Glucose production, glucose oxidation, and nonoxidative glucose disposal rates for individual patients are shown in Table 2.

In 13 of 16 patients, the GPR was $>1.0 \mathrm{mg} \cdot \mathrm{kg}^{-1} \cdot \mathrm{min}^{-1}$ while they were receiving a continuous glucose infusion of $4.2 \pm 0.5$ $\mathrm{mg} \cdot \mathrm{kg}^{-1} \cdot \mathrm{min}^{-1}$. Although the glucose production was lower in SGA infants, the difference did not reach significance $(p=$ 0.051 ). We found the GPR to be twice as high in infants (four AGA and one SGA) from mothers who had received steroids compared with the infants not exposed to corticosteroids (2.28 $\pm 1.05 \mathrm{mg} \cdot \mathrm{kg}^{-1} \cdot \mathrm{min}^{-1}$ versus $1.13 \pm 0.80 \mathrm{mg} \cdot \mathrm{kg}^{-1} \cdot \mathrm{min}^{-1}, p=$ 0.036). Comparing these two groups on clinical variables, we could not find any differences.

The oxidation rate was found to be lower than the glucose infusion rate in both groups of infants $(p=0.0052)$. We did not observe any difference in glucose oxidation between AGA and SGA infants $(p=0.78)$.

The total $\mathrm{Ra}$ was correlated with head circumference $(r=$ $0.58, p=0.02$ ). Head circumference, however, was not correlated with total glucose oxidation $(r=0.06)$, nor was the head circumference to body weight ratio $(r=-0.16)$.

The ventilatory status and the infant's condition just after birth, reflected by the Apgar score at $5 \mathrm{~min}$, were not related to the glucose kinetics. We were also unable to show any effect of the antenatally administered $\beta$-sympaticomimetics.

The median insulin level in the AGA infants was $31.5(22-87)$ $\mathrm{pmol} / \mathrm{L}$ compared with $22.4(22-28) \mathrm{pmol} / \mathrm{L}$ in the SGA infants $(p=0.19)$. No correlation could be seen with GPR (Fig. 3). Glucagon levels, which were only measured in five patients in each group, were lower in AGA infants (Fig. 4).

The median IGF-I level was $1.1(0.4-2.4) \mathrm{nmol} / \mathrm{L}$; the IGF-II levels were much higher $[26.9(10.7-34.4) \mathrm{nmol} / \mathrm{L}]$. Male infants had statistically lower IGF-I levels than their female counterparts [0.7 $(0.2-2.1) \mathrm{nmol} / \mathrm{L}$ for male infants versus $2.6(1.5-3.1) \mathrm{nmol} /$ $\mathrm{L}$ for female infants, $p=0.048$ ]. There was no correlation between IGF-I levels and glucose production or oxidation rate. IGF-II level and Ra were negatively correlated ( $r=-0.55, p=$ 0.042 ). The FFA level, a measure of lipolysis, was negatively correlated with IGF-I level $(r=-0.59, p=0.032)$. No correlation was found between glucose oxidation rate and FFA levels $(r=$ $-0.02)$. The FFA levels were not different between groups $[0.20$ (0.13-0.33) mmol/L (AGA) versus $0.16(0.16-0.27) \mathrm{mmol} / \mathrm{L}$ (SGA)]. Glucose concentration did not correlate with GPR $(r=$ $0.34)$, oxidation $(r=-0.33)$, or nonoxidative disposal rates $(r=$ $0.16)$.

\section{DISCUSSION}

Approximately $50 \%$ of plasma glucose was oxidized in our group of 1-d-old preterm infants (range, 27 to $82 \%$ ). In preterm infants 7 to $28 \mathrm{~d}$ old, the percentage of the glucose rate of disappearance used for oxidation is higher $(>60 \%)(19)$. The data shown in the present article match very well with data obtained from studies in fetal lambs and term infants. Fetal glucose utilization rate measured in lambs was $4.7 \mathrm{mg} \cdot \mathrm{kg}^{-1} \cdot \mathrm{min}^{-1}$, with a glucose oxidation rate of $2.5 \mathrm{mg} \cdot \mathrm{kg}^{-1} \cdot \mathrm{min}^{-1}(22)$. In 11 fasted human newborns, Denne and Kalhan (7) measured a glucose oxidation rate of $2.53 \mathrm{mg} \cdot \mathrm{kg}^{-1} \cdot \mathrm{min}^{-1}$, which represented $53 \%$ of the glucose turnover.

We found that the amount of glucose oxidized is less than the amount of glucose infused in 11 of 14 patients. The amount of calories provided by glucose oxidation is far less than the total energy expenditure measured recently by Hazan et al. (23). They found a metabolic rate of 40 to $50 \mathrm{kcal} \cdot \mathrm{kg}^{-1} \cdot \mathrm{d}^{-1}$ in ventilated infants, measured shortly after birth. On average, the oxidation of glucose in our study population produced less than $17 \mathrm{kcal}$. $\mathrm{kg}^{-1} \cdot \mathrm{d}^{-1}$ and thus fell short of satisfying the energy expenditure. To meet the energy expenditure, other substances have to be oxidized. Bougnères et al. studied palmitate and glycerol turnover 


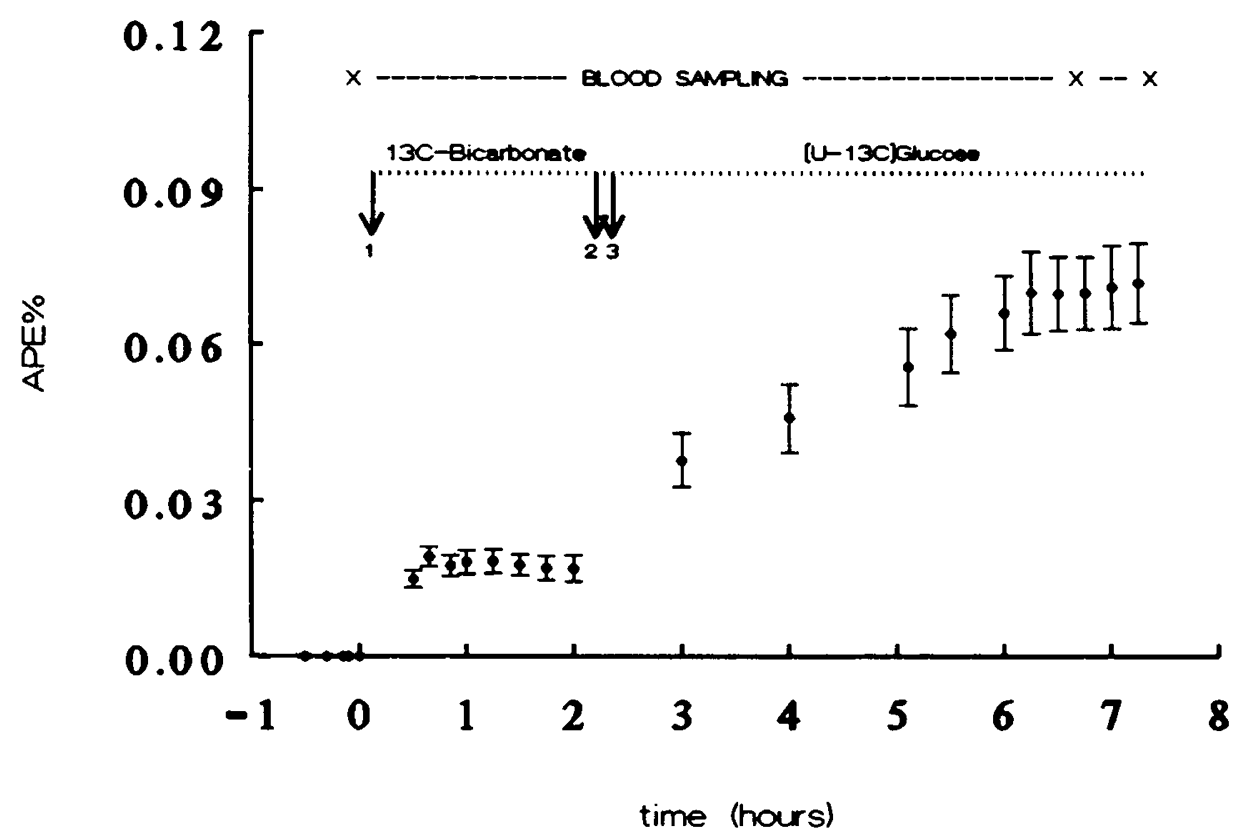

Fig. 2. The mean values for all time points of the ${ }^{13} \mathrm{CO}_{2}$ excretion curve. Values are presented as mean \pm SEM. Enrichment ( $y$ axis) is expressed as atom percent excess above basal enrichment. A plateau in enrichment is seen during both the $\mathrm{NaH}^{13} \mathrm{CO}_{3}$ infusion and the [ $\left.\mathrm{U}_{-}{ }^{13} \mathrm{C}\right] \mathrm{glucose}$ infusion. 1, Priming dose of $8.7 \mu \mathrm{mol} \mathrm{NaH}{ }^{13} \mathrm{CO}_{3} / \mathrm{kg} ; 2$, priming dose of $10.4 \mu \mathrm{mol} \mathrm{NaH}^{13} \mathrm{CO}_{3} / \mathrm{kg} ; 3$, priming dose of $8.7 \mu \mathrm{mol}\left[\mathrm{U}-{ }^{13} \mathrm{C}\right]$ glucose $/ \mathrm{kg}$.

Table 2. Glucose kinetics of infants*

\begin{tabular}{lccccc}
\hline & GIR & $\mathrm{Ra}=\mathrm{Rd}$ & GPR & Oxidation & NOD \\
\hline AGA & & & & & \\
1 & 4.1 & 5.3 & 1.2 & 2.1 & 3.2 \\
2 & 4.1 & 5.7 & 1.6 & 2.0 & 3.7 \\
3 & 4.2 & 8.2 & 4.0 & 4.5 & 3.7 \\
4 & 4.2 & 6.0 & 1.8 & 3.5 & 2.4 \\
5 & 3.9 & 6.0 & 2.1 & 2.1 & 3.9 \\
6 & 4.2 & 6.6 & 2.4 & 3.5 & 3.1 \\
7 & 3.9 & 6.5 & 2.6 & 1.7 & 4.8 \\
8 & 4.4 & 5.8 & 1.4 & 4.7 & 1.1 \\
9 & 4.2 & 4.2 & 0.0 & 1.7 & 2.5 \\
10 & 4.2 & 5.3 & 1.1 & 3.2 & 2.1 \\
Mean AGA & $4.1 \pm 0.2$ & $6.0 \pm 1.0$ & $1.8 \pm 1.1$ & $2.9 \pm 1.1$ & $3.1 \pm 1.1$ \\
SGA & & & & & \\
11 & 2.9 & 5.0 & 2.1 & 3.8 & 1.2 \\
12 & 5.1 & 6.1 & 1.0 & 2.5 & 3.6 \\
13 & 4.6 & 4.8 & 0.2 & 3.5 & 1.3 \\
14 & 4.4 & 5.6 & 1.2 & 1.9 & 3.6 \\
15 & 4.2 & 5.2 & 1.0 & NM & \\
16 & 4.9 & 5.2 & 0.3 & NM & \\
Mean SGA & $4.3 \pm 0.8$ & $5.3 \pm 0.5$ & $1.0 \pm 0.7$ & $2.9 \pm 0.9$ & $2.4 \pm 0.3$ \\
\hline
\end{tabular}

* All results are given in $\mathrm{mg} \cdot \mathrm{kg}^{-1} \cdot \mathrm{min}^{-1}$. GIR, glucose infusion rate; $\mathrm{Rd}$, rate of disappearance; NOD, nonoxidative disposal; NM, not measured. GPR and NOD are calculated according to equation 2 in the Appendix.

in full-term, 1-d-old neonates (24). Using $\left[1-{ }^{13} \mathrm{C}\right]$ palmitic acid as a tracer, they found FFA fluxes comparable to fluxes in fasted adults. By assuming an oxidation rate of $30 \%$, the energy obtained by fat oxidation was estimated to be 11 to $13.5 \mathrm{kcal} \cdot \mathrm{kg}^{-1}$. $\mathrm{d}^{-1}$. From indirect calorimetry studies, however, Patel and Kalhan (25) recently reported the oxidation rate of fatty acids in fasted AGA term infants to be equivalent to $25 \mathrm{kcal} \cdot \mathrm{kg}^{-1} \cdot \mathrm{d}^{-1}$ and in SGA infants to be $30 \mathrm{kcal} \cdot \mathrm{kg}^{-1} \cdot \mathrm{d}^{-1}$. The latter data are much more in agreement with our findings, giving the following energy partition: $35-40 \%$ is delivered by glucose oxidation, $50-$ $60 \%$ by fatty acid oxidation, and the remaining energy needed could be derived from protein oxidation. Studies on fatty acid oxidation and amino acid oxidation have to be performed in preterm infants to confirm this picture of energy partition.

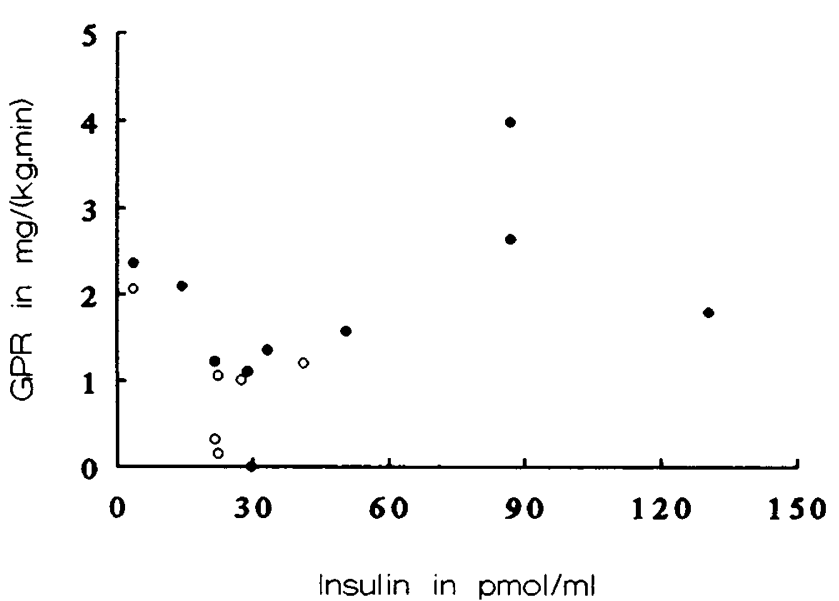

Fig. 3. Insulin levels and GPR. AGA infants are represented by filled circles, SGA infants by open circles. We found no significant correlation.

The nonoxidative disposal rate was approximately $3 \mathrm{mg} \cdot \mathrm{kg}^{-1}$. $\min ^{-1}$. A large part, $2 \mathrm{mg} \cdot \mathrm{kg}^{-1} \cdot \mathrm{min}^{-1}$, can be explained by glucose being shuttled into different pathways, for instance the pentose phosphate cycle. A simultaneous release of glucose coming from these pathways will result in a GPR of $2 \mathrm{mg} \cdot \mathrm{kg}^{-1} \cdot \mathrm{d}^{-1}$. Other glucose molecules might be used as carbon skeleton for amino acids. Lipogenesis as a major route of nonoxidative disposal might be important in patients who are in an anabolic state and receive enough glucose and calories. The infants in the present study were in a catabolic state, with low insulin levels, and received a low energy intake. Although lipogenesis may still take place under these circumstances, it is not likely that this pathway is an important route of carbon disposal. Finally, some glucose might be stored as glycogen. The present study does not allow us to distinguish between these different routes of carbon disposal.

Complete suppression of GPR is found in adults at an intake of $4 \mathrm{mg} \cdot \mathrm{kg}^{-1} \cdot \mathrm{min}^{-1}$ or higher (26) but not in preterm infants as shown in this study and in other studies $(6,8,10,11,27)$. The large differences found in the rate of glucose appearance (range $4.2-7.2 \mathrm{mg} \cdot \mathrm{kg}^{-1} \cdot \mathrm{min}^{-1}$ ) in neonates might be explained by the different tracers used (8). With use of $\left[1-{ }^{13} \mathrm{C}\right]$ glucose as a tracer 


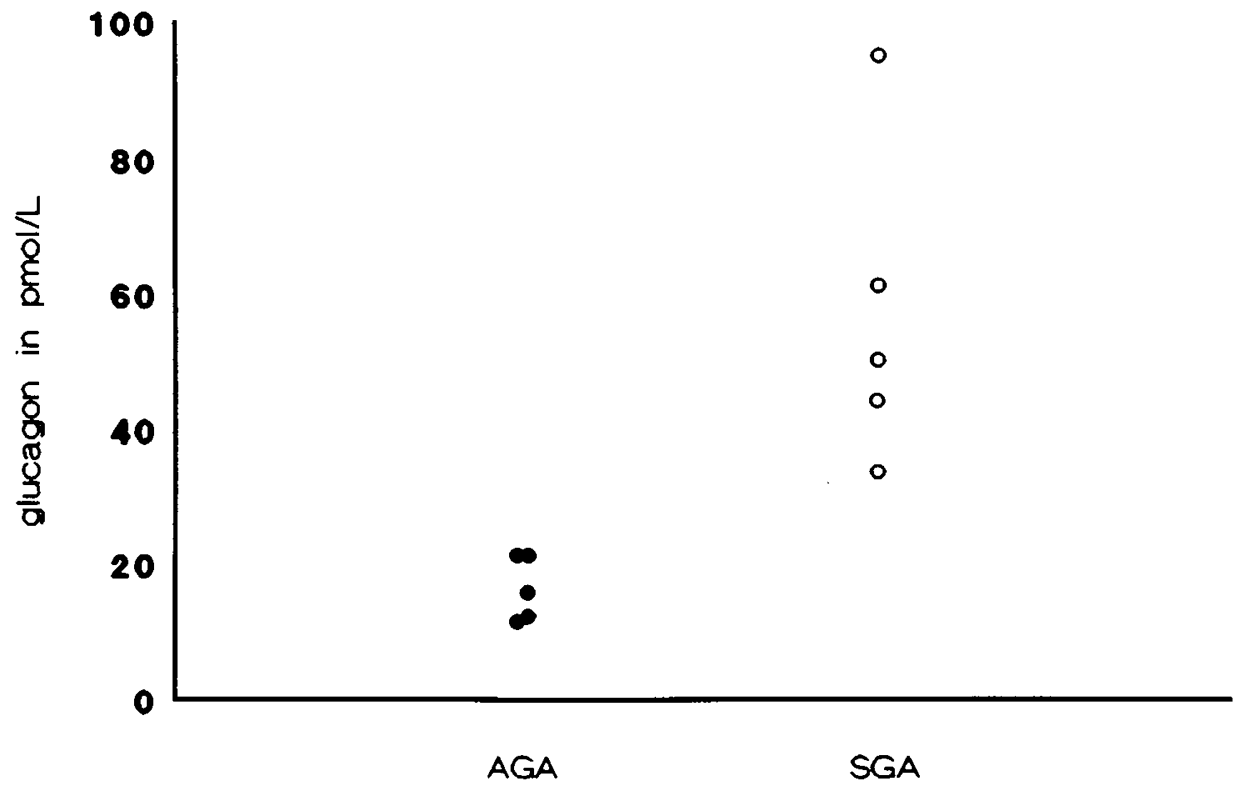

Fig. 4. Glucagon concentrations in AGA (filled circles) and SGA (open circles) infants.

as compared with $\left[6,6-{ }^{2} \mathrm{H}_{2}\right]$ glucose and $\left[\mathrm{U}-{ }^{13} \mathrm{C}\right]$ glucose (with measurement of the $\mathrm{m}+6$ enrichment in plasma), lower values of the $\mathrm{Ra}$ will be obtained because of recycling of the label.

Glucose recycling has been measured in neonates and ranged from 3 to $20 \%$ of the $\mathrm{Ra}$ when two different tracers, $\left[6,6-{ }^{2} \mathrm{H}_{2}\right]$ glucose and $\left.\left[1-{ }^{13} \mathrm{C}\right]\right)$ glucose, were used (8). Using $\left[\mathrm{U}_{-}{ }^{13} \mathrm{C}\right]$ glucose and determining the difference of the $\mathrm{m}+6$ and the $\mathrm{m}+1$ enrichment a value of $36 \%$ has been found (7). We measured the glucose oxidation by multiplying the rate of disappearance with the recovery of the label in expiratory air. We used the $m+6$ enrichment to calculate the rate of glucose disappearance, but oxidation of glucose molecules with one to five ${ }^{13} \mathrm{C}$-atoms will also result in labeled $\mathrm{CO}_{2}$ in expiratory air. The glucose oxidation found in this study could thus be an overestimation, emphasizing even more the relatively small contribution of glucose oxidation to the energy demand of preterm infants on the first postnatal day.

This study shows that antenatal steroid administration increases the GPR. Many corticosteroids like betamethasone have a gluconeogenetic effect that is more potent than the effect of prednisone. The drug administered to the mother still seems to exert an effect $18 \mathrm{~h}$ after birth in these infants. Whether there is a long-term effect of these drugs is not known, but the potential effect should be considered when interpreting glucose kinetics in preterm neonates.

Glucose is believed to be the main energy substrate for the brain (5). Bier et al. (27) found a linear relationship between GPR in fasted preterm infants and estimated brain weight. We measured head circumference and found no correlation with glucose oxidation. Also, asymmetric infants, i.e. infants with a high head circumference to body weight ratio, did not oxidize more glucose. Glucose might still be the main substrate as an energy source, but our data do not support the hypothesis that the brain is the main site of glucose oxidation. Ketone bodies, glycerol, and lactate might also play significant roles as energy sources for the brain (28).

The role played by the major glucoregulatory hormones in adults, insulin and glucagon, in controlling the glucose homeostasis in the preterm infant is not yet clear (29). Susa et al. (30) found a suppression of GPR by insulin infusion in newborn lambs. No effect of insulin and glucose infusions on glucagon levels was found. In our study, we found no correlation between insulin levels measured at the end of the study and any of the glucose kinetic parameters. Also, the level of glucagon was not correlated with the GPR.
Insulin might also exert an effect via IGF. IGF levels are increasing from wk 22 of gestation onward, which might be an indicator of some importance regarding the metabolic effects of these factors around birth $(31,32)$. IGF-I infusion has been shown to increase glucose uptake and to inhibit hepatic glucose production in healthy adults and in rats (33-35). It has been shown in normal rats that the effects of IGF-I and insulin on glucose metabolism are identical and additive (36). Insulin itself is said to promote IGF-I production (37), although in this study we could not find a correlation with IGF-I. We did find a negative correlation between IGF-I and FFA levels, indicating a inhibitory effect of IGF-I on lipolysis. IGF-I levels, similar to insulin levels, were not correlated with glucose metabolism.

Surprisingly, we found a negative correlation between IGF-II and the rate of glucose appearance. The potency and working mechanism of IGF-II regarding glucose metabolism is unclear, but usually IGF-II is said to be a less potent glucoregulatory hormone than IGF-I. In fasted lambs, IGF-II infusion led to a small increase in glucose uptake (15\%), whereas IGF-I increased glucose clearance by $55 \%$ (35). In contrast to insulin, both IGFI and IGF-II failed to suppress glucose production in that study. Plasma IGF-II levels were not measured, and IGF-I showed an effect only at levels of $240 \mu \mathrm{g} / \mathrm{L}(31.4 \mathrm{pmol} / \mathrm{L})$ and not at 67 $\mu \mathrm{g} / \mathrm{L}(8.8 \mathrm{pmol} / \mathrm{L})$. The levels found for IGF-I and IGF-II in our study are lower than those reported by Lassarre et al. (31) found in cord blood in utero. We found no differences between levels in growth-retarded and AGA infants.

It may well be that, in spite of relatively stable plasma glucose levels, a relatively long time is needed to stabilize the hormones involved in glucose metabolism after the stressful event of birth. Active intervention by an infusion of recombinant human IGF or insulin could have given different results.

In conclusion, we observed that the contribution of the glucose oxidation to the energy demand is relatively small on the first day of life in preterm infants. It is not yet clear to what extent the oxidation of other substrates contributes to the energy demand. Insulin, glucagon, or IGF-I levels, measured once as in this study, are not related to glucose metabolism in preterm infants during the first day of life.

Acknowledgments. The authors thank Paul Adan, Anneke Boerlage, Joke van 't Hof, and Darcos Wattimena for their help in performing the study; Dr. G. J. Bruining and Dr. S. L. S. Drop for critically reviewing the manuscript; and the nurses and neonatology staff for expert patient care. 


\section{REFERENCES}

1. Anand RS, Sperling MA, Ganguli S, Natanielsz PW 1979 Bidirectional placental transfer of glucose and its turnover in fetal and maternal sheep. Pediatr Res 13:783-787

2. Coltart TM, Beard RW, Turner RC, Oakley NW 1969 Blood glucose and insulin relationship in the human mother and foetus before onset of labour. Br Med J [Clin Res] 4:17-21

3. Morriss FH, Makowski EL, Meschia G, Battaglia FC 1975 The glucose/oxygen quotient of the term human fetus. Biol Neonate 25:44-52

4. Senterre J, Karlberg P 1970 Respiratory quotient and metabolic rate in normal full-term and small for date newborn infants. Acta Paediatr Scand 59:653658

5. Cowett R 1985 Pathophysiology, diagnosis and management of glucose homeostasis in the neonate. In: Lockhart JD (ed) Current Problems in Pediatrics. Year Book Medical Publishers, Chicago, pp 6-47

6. Cowett RM, Oh W, Schwartz R 1983 Persistent glucose production during glucose infusion in the neonate. $\mathrm{J}$ Clin Invest 71:467-475

7. Denne SC, Kalhan SC 1986 Glucose carbon recycling and oxidation in human newborns. Am J Physiol 251:E71-E77

8. Kalhan SC, Bier DM, Savin SM, Adam PAJ 1980 Estimation of glucose turnover and ${ }^{13} \mathrm{C}$ recycling in the human newborn by simultaneous $\left[1-{ }^{13} \mathrm{C}\right]$ glucose and $\left[6,6-{ }^{2} \mathrm{H}_{2}\right]$ glucose tracers. J Clin Endocrinol Metab 50:456-460

9. Baarsma R, Chapman T, van Asselt W, Berger R, Okken A 1990 Glucose kinetics in pre-term and near-term small for gestational age newborn infants. In: Chapman TE, Berger R, Reingoud DJ (eds) Stable Isotopes in Paediatric Nutritional and Metabolic Research. Intercept Ltd, Andover, UK, pp 123132

10. Cowett RM, Susa JB, Oh W, Schwartz R 1984 Glucose kinetics in glucose infused small for gestational age infants. Pediatr Res 18:74-79

11. Kalhan SC, Oliven A, King KC, Lucero C 1986 Role of glucose in regulation of endogenous glucose production in the human newborn. Pediatr Res 20:49-52

12. Usher RH, McLean F 1969 Intrauterine growth of live-born Caucasian infants at sea level: standards obtained from measurements in 7 dimensions of infants born between 25 and 44 weeks of gestation. J Pediatr 74:901-910

13. Ballard JL, Khoury JC, Wedig K, Wang L, Eilers-Walsman BL, Lipp R 1991 New Ballard score, expanded to include extremely premature infants. $J$ Pediatr 119:417-423

14. Tenenbaum D, Cowett RM 1985 Mechanisms of beta sympathomimetic action on neonatal glucose homeostasis in the lamb. J Pediatr 107:588-592

15. Brazy JE, Pupkin MJ 1979 Effects of maternal isoxsuprine administration on preterm infants. J Pediatr 94:444-448

16. Epstein MF, Nicholls E, Stubblefield PG 1979 Neonatal hypoglycemia after beta-sympathomimetic tocolytic therapy. J Pediatr 94:449-453

17. Hallman M, Merrit TA, Jarvenpaa AL, Boynton B, Mannino F, Gluch L, Moore T, Edwards D 1985 Exogenous human surfactant for treatment of severe respiratory distress syndrome: a randomized prospective study. J Pediatr 106:963-969

18. Van Aerde JEE, Sauer PJJ, Pencharz PB, Canagarayar U, Beesley J, Smith JM, Swyer PR 1985 The effect of energy intake and expenditure on the recovery of ${ }^{13} \mathrm{CO}_{2}$ in the parenterally fed neonate during a 4-hour primed constant infusion of $\mathrm{NaH}^{13} \mathrm{CO}_{3}$. Pediatr Res 19:806-810

19. Lafeber HN, Sulkers EJ, Chapman TE, Sauer PJJ 1990 Glucose production and oxidation in preterm infants during total parenteral nutrition. Pediatr Res 28:153-157

20. Hokken-Koelega ACS, Hackeng WHL, Stijnen T, Wit JM, de Muinck KeizerSchrama SMPF, Drop SLS 1990 Twenty-four-hour plasma growth hormone (GH) profiles, urinary $\mathrm{GH}$ excretion and plasma insulin-like growth factorI and -II levels in prepubertal children with chronic renal insufficiency and severe growth retardation. J Clin Endocrinol Metab 71:688-695

21. Sulkers EJ, van Goudoever JB, Leunisse C, Degenhart HJ, Lafeber HN, Sauer PJJ 1991 Determination of carbon-labelled substrate oxidation rates without measuring $\mathrm{VCO}_{2}$. In: Lafeber $\mathrm{HN}$ (ed) Fetal and Neonatal Physiological Measurements. Elsevier, New York, pp 297-304

22. Hay WW, DiGiacomo JE, Meznarich HK, Hirst K, Zerbe G 1989 Effects of glucose and insulin on fetal glucose oxidation and oxygen consumption. Am J Physiol 256:E704-E713

23. Hazan J, Chessex P, Piedboeuf B, Bourgeois M, Bard H, Long W 1992 Energy expenditure during synthetic surfactant replacement therapy for neonatal respiratory distress syndrome. J Pediatr 1992:120:S29-S33

24. Bougnères PF, Karl IE, Hillman LS, Bier DM 1982 Palmitate and glycerol turnover and the contribution of glycerol to neonatal hepatic glucose output. $\mathrm{J}$ Clin Invest 70:262-270

25. Patel D, Kalhan S 1992 Glycerol metabolism and triglyceride-fatty acid cycling in the human newborn: effect of maternal diabetes and intrauterine growth retardation. Pediatr Res 31:52-58

26. Wolfe RR, Shaw JH, Jahoor F, Herndon DN, Wolfe MH 1986 Response to glucose infusion in humans: role of changes in insulin concentration. Am J Physiol 250:E306-E311

27. Bier DM, Leake RD, Haymond MW, Arnold KJ, Sperling MA, Kipnis DM 1977 Measurement of "true" glucose production rates in infancy and childhood with 6,6-dideuteroglucose. Diabetes 26:1016-1023

28. Amiel SA, Archibald HR, Chusney G, Williams AJK, Gale EAM 1991 Ketone infusion lowers hormonal responses to hypoglycaemia: evidence for acute cerebral utilisation of a non-glucose fuel. Clin Sci 81:189-194

29. Grasso S, Fallucca F, Romeo MG, Distefano G, Sciullo E, Reitano G 1990
Glucagon and insulin secretion in low birthweight preterm infants. Acta Paediatr Scand 79:280-285

30. Susa JB, Cowett RM, Oh W, Schwartz R 1979 Suppression of gluconeogenesis and endogenous glucose production by exogenous insulin administration in the newborn lamb. Pediatr Res 13:594-598

31. Lasarre C, Hardouin S, Daffos F, Forestier F, Frankenne F, Binoux M 1991 Serum insulin-like growth factors and insulin-like growth factor binding proteins in the human fetus. Relationships with growth in normal subjects and in subjects with intrauterine growth retardation. Pediatr Res 29:219 225

32. Bennett A, Wilson DM, Liu F, Nagashima R, Rosenfeld RG, Hintz RL 1983 Levels of insulin-like growth factors I and II in human cord blood. J Clin Endocrinol Metab 57:609-612

33. Boulware SD, Tamborlane WV, Matthews LS, Sherwin RS 1992 Diverse effects of insulin-like growth factor I on glucose, lipid and amino acid metabolism. Am J Physiol 262:E130-E133

34. Moxley RT, Arner P, Moss A, Skottner A, Fox M, James D, Livingston JN 1990 Acute effects of insulin-like growth factor I and insulin on glucose metabolism in vivo. Am J Physiol 259:E561-E567

35. Douglas RG, Gluckman PD, Ball K, Breier B, Shaw JHF 1991 The effects of infusion of insulin-like growth factor (IGF) I, IGF-II and insulin on glucose and protein metabolism in fasted lambs. J Clin Invest 88:614-622

36. Rosetti L, Frontoni S, Dimarchi R, DeFronzo RA, Giaccari A 1991 Metabolic effects of IGF-I in diabetic rats. Diabetes 40:444-448

37. Labib M, Teale D, Marks V 1990 Insulin-like growth factor I in patients with hypoglycemia. Ann Clin Biochem 27:107-109

\section{APPENDIX}

Calculations regarding glucose metabolism. The rate of glucose appearance is calculated as follows:

$$
\mathrm{Ra}=\left(\frac{\mathrm{IE} \text { infusion }}{\mathrm{IE}_{\text {plasma }}}-1\right) \times \mathrm{I}(\mathrm{G})
$$

where $\mathrm{Ra}$ is the rate of appearance, $\mathrm{IE}_{\text {infusion }}$ is the isotopic enrichment of the infusate, $\mathrm{IE}_{\text {plasma }}$ is the isotopic enrichment $(\mathrm{m}+6)$ of the plasma glucose, and $\mathrm{I}(\mathrm{G})$ is the $\left[\mathrm{U}-{ }^{13} \mathrm{C}\right] \mathrm{glucose}$ infusion rate in $\mu \mathrm{mol} \cdot \mathrm{kg}^{-1} \cdot \mathrm{min}^{-1}$.

Under steady state conditions, the rate of glucose appearance is equal to the rate of glucose disappearance. Glucose can enter the glucose pool by a glucose infusion and by glucose production from other substrates, e.g. glycerol and some amino acids. Glucose can leave the pool by oxidation or nonoxidative disposal.

$$
\mathrm{Ra}=\mathrm{GIR}+\mathrm{GPR}=\mathrm{GO}+\mathrm{NOD}=\mathrm{Rd}
$$

where GIR is the glucose infusion rate, GO is glucose oxidation rate, NOD is nonoxidative disposal rate, and $\mathrm{Rd}$ is rate of disappearance.

To measure the glucose oxidation rate with the use of a continuous infusion of $\left[\mathrm{U}-{ }^{13} \mathrm{C}\right]$ glucose, usually a correction factor is used to compensate for the losses of labeled carbon within the bicarbonate pool. This correction factor can be determined beforehand in a separate study or calculated from the energy intake (18). The equation used for the oxidation is:

$$
\mathrm{GO}=\frac{\mathrm{VCO}_{2}(\mathrm{G}) \times \mathrm{IE}_{\mathrm{CO}_{2}}(\mathrm{G})}{\mathrm{I}(\mathrm{G}) \times \mathrm{c}} \times \mathrm{Ra}
$$

where $\mathrm{VCO}_{2}(\mathrm{G})$ is the rate of $\mathrm{CO}_{2}$ excretion in $\mu \mathrm{mol} \cdot \mathrm{kg}^{-1} \cdot \mathrm{min}^{-1}$ during the $\left[\mathrm{U}_{-}^{13} \mathrm{Clglucose}\right.$ infusion, $\mathrm{IE}_{\mathrm{CO}_{2}}(\mathrm{G})$ is the isotopic enrichment of expired $\mathrm{CO}_{2}$ at plateau, $\mathrm{I}(\mathrm{G})$ is the $\left[\mathrm{U}^{13} \mathrm{C}\right]$ glucose infusion rate in $\mu \mathrm{mol}{ }^{13} \mathrm{C} \cdot \mathrm{kg}^{-1} \cdot \mathrm{min}^{-1}$, and $\mathrm{c}$ is the correction factor.

A more accurate method is to measure the bicarbonate retention for each infant individually. The correction factor is determined using the following equation:

$$
\mathrm{c}=\frac{\mathrm{VCO}_{2}(\mathrm{~B}) \times \mathrm{IE}_{\mathrm{CO}_{2}}(\mathrm{~B})}{\mathrm{I}(\mathrm{B})}
$$

where $\mathrm{VCO}_{2}(\mathrm{~B})$ is the rate of $\mathrm{CO}_{2}$ excretion in $\mu \mathrm{mol} \cdot \mathrm{kg}^{-1} \cdot \mathrm{min}^{-1}$ during the $\mathrm{NaH}^{13} \mathrm{CO}_{3}$ infusion, $\mathrm{IE}_{\mathrm{CO}_{2}}(\mathrm{~B})$ is the isotopic enrichment of expired air at plateau during the $\mathrm{NaH}^{13} \mathrm{CO}_{3}$ infusion, and $\mathrm{I}(\mathrm{B})$ is the $\mathrm{NaH}^{13} \mathrm{CO}_{3}$ infusion rate in $\mu \mathrm{mol} \cdot \mathrm{kg}^{-1} \cdot \mathrm{min}^{-1}$.

Combining equations 3 and 4 leads to: 


$$
\mathrm{GO}=\frac{\mathrm{VCO}_{2}(\mathrm{G}) \times \mathrm{IE}_{\mathrm{CO}_{2}}(\mathrm{G})}{\mathrm{I}(\mathrm{G}) \times \frac{\mathrm{VCO}_{2}(\mathrm{~B}) \times \mathrm{IE}_{\mathrm{CO}_{2}}(\mathrm{~B})}{\mathrm{I}(\mathrm{B})}} \times \mathrm{Ra}
$$

Since the $\mathrm{NaH}^{13} \mathrm{CO}_{3}$ infusion is immediately followed by the [U${ }^{13} \mathrm{C}$ ]glucose infusion and no changes are made in the intake of the infants, we can assume that $\mathrm{VCO}_{2}(\mathrm{G})=\mathrm{VCO}_{2}(\mathrm{~B})$. Removing the term $\mathrm{VCO}_{2}$ from both numerator and denominator, the following equation can be derived:

$$
\mathrm{GO}=\frac{\mathrm{IE}_{\mathrm{CO}_{2}}(\mathrm{G}) \times \mathrm{I}(\mathrm{B})}{\mathrm{I}(\mathrm{G}) \times \mathrm{IE}_{\mathrm{CO}_{2}}(\mathrm{~B})} \times \mathrm{Ra}
$$

Equation 6 shows that, in case of a constant $\mathrm{CO}_{2}$ production over a few hours, it is not necessary to measure $\mathrm{VCO}_{2}$. This creates the opportunity to study ventilated patients, as was done in the present study.

\section{Announcement}

\section{Charles E. Culpeper Foundation Scholarships in Medical Science}

The Charles E. Culpeper Foundation is currently accepting applications for its 1994 Scholarships in Medical Science Program designed to support the career development of academic physicians.

Up to three awards of $\$ 100,000$ per year for 3 years will be made to United States medical schools on behalf of candidates who are U.S. citizens, who have received their M.D. degree from a U.S. medical school in 1985 or later, and who are judged worthy of support by virtue of the quality of their research proposals. All scientific research relevant to human health is eligible for consideration. No institution may nominate more than one candidate.

In selecting awardees, emphasis will be on identifying young physicians with clear potential for making substantial contributions to science as academic physicians. Since January 1988,18 physicians have been selected as Charles E. Culpeper Foundation Medical Scholars.

Deadline for applications is August 16, 1993. Awards will be announced by January 14, 1994 for activation on or about July 1, 1994. Application forms and instructions may be obtained by contacting the Charles E. Culpeper Foundation at Financial Centre, 695 East Main Street, Suite 404, Stamford, CT 06901. 